\title{
Application of the numerical model SWAN in locations with vegetation in the Tiete-Paraná waterway—lake of Ilha Solteira's Dam—Brazil
}

\author{
A.S. Vieira \\ Universidade Estadual Paulista, UNESP, Brazil \\ I.C. Gregório \\ Science Faculty of Lisbon University, Lisbon, Portugal \\ C.J.E.M. Fortes \\ National Laboratory of Civil Engineering, Lisbon, Portugal \\ T. Suzuki \\ Flanders Hydraulics Research, Antwerp, Belgium \\ G. Maciel \\ Universidade Estadual Paulista, UNESP, Brazil
}

\begin{abstract}
This paper describes the application of SWAN-VEG to the lake of Ilha Solteiras's damSão Paulo, Brazil that is part of the Tietê-Paraná waterway, in order to analyze the influence of vegetation on the reduction of energy of the waves near the lake margins. First the model is applied considering a constant water depth in the entire dam reservoir and a small area of vegetation is implemented at the end of the dam. Several values of velocity and wind directions as well as different vegetation characteristics are tested. Then, the real bathymetry of the lake is considered as well as vegetation in certain margins of the lake. Several wind conditions are tested and compared with the situation with and without vegetation.
\end{abstract}

\section{INTRODUCTION}

The Tietê-Paraná Waterway is a navigation route located in the south, southeast and center-west regions of Brazil. It allows the navigation of the cargo and passengers transportation along the Paraná and Tietê rivers. It is considered to be important for the flow of the agricultural production for the states of Mato Grosso, Mato Grosso do Sul, Goiás and for a portion of Rondônia, Tocantis and Minas Gerais. Two million tons of cargo were transported through this waterway in 2001. It holds twelve terminals, scattered across 76 millions of hectares. The start of this system promoted the implementation of 23 industrial hubs, 17 touristic hubs and 12 distribution centers, therefore directly creating around 4 thousand jobs. Figure 1 shows the segment of the Tietê-Paraná Waterway that is part of the Lake of Ilha Solteira's Dam.

In certain areas of this lake, the waves generated by winds and by the passage of vessels that frequently cross the waterway are responsible for the shore erosion and big mudslides. To alleviate these problems, the usage of vegetation, that leads to the consequential mitigation of the generated waves, is an appealing option as it dissipates wave energy without environmental and economic loads. Therefore, it is fundamental to analyse the vegetation influence on the reduction of energy of the waves near the lake shore.

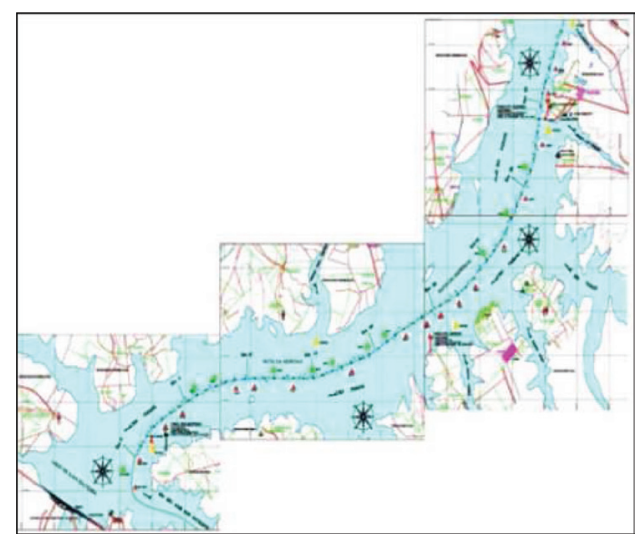

Figure 1. Representation of the segment/route of the Tietê-Paraná waterway. 
On the previous work of Vieira et al. $(2011,2013)$ the SWAN model (Booij et al., 1999) was applied to characterize the wind waves on the dam reservoir (without vegetation) which has been evaluated as an excellent alternative for the determination of wave properties in regions lacking data. Note that for Ilha Solteira lake there is an extensive monitoring measuring plan carried out within the framework of the research project FINESP-ONDISA5, UNESP 1997, 2008. However, those measurements are made in only four points distributed at the lake, which cannot give an overview of the whole lake as the numerical model do.

To analyze the influence of the vegetation on reduction of wave energy, the intent of this paper is to apply the most recent version of the numerical model SWAN (version 41.01, SWAN team, 2014) that includes the energy dissipation due to vegetation, SWAN-VEG (Suzuki et al., 2011), in the lake of Ilha Solteira's dam area. The model is applied for wind data obtained from a instrumentation tree installed in the lake at around 250 meter away from the shore, in which there is implemented a pressure sensor (from the brand Druck) and a 2D sonic anemometer. We analyse the effect of the existing vegetation regarding the attenuation of the wave height. First, a constant depth in the entire dam reservoir is considered and several values of velocity and wind directions as well as different vegetation characteristics are tested. Then, considering the real water depth of the lake, tests are performed without and with vegetation located at several places around the lake. For both situations, several wave conditions and vegetation characteristics are considered.

This paper begins with a short description of the study area (section 2) and the data collection. Then, the description of the numerical model used (section 3) and its application to the study area (section 4) is presented, considering a constant and the actual bathymetries. A discussion of the results obtained for the different conditions is presented in section 5. Finally, the conclusions are drawn in section 6 .

\section{STUDY AREA}

\subsection{General overview}

The study area is the Ilha Solteira dam reservoir, the third largest dam in Brazil. It is located near Ilha Solteira city, one of Brazil's city councils at the northwest of São Paulo state, Brazil (Fig. 2), located $699 \mathrm{~km}$ away from São Paulo capital. The artificial lake has an extension of $100 \mathrm{~km}$ and its dam is located at latitude $20^{\circ} 25^{\prime} 58^{\prime \prime} \mathrm{S}$, longitude $51^{\circ} 20^{\prime} 33^{\prime \prime} \mathrm{W}$, and an altitude of $335 \mathrm{~m}$, approximately. This dam is one of the most important
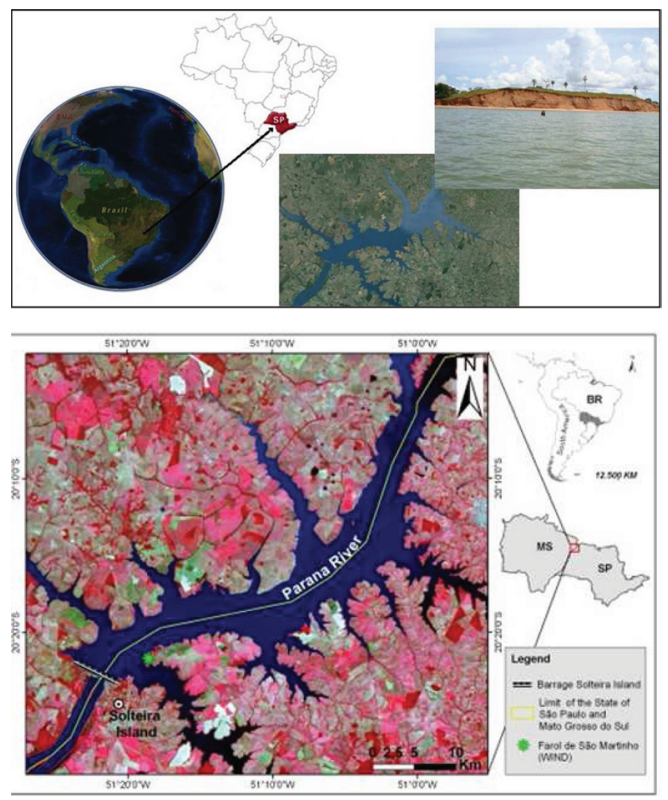

Figure 2. Dam reservoir of Ilha Solteira, São Paulo, Brazil. General views.

dams in the Tietê-Paraná waterway and is located where the rivers Tietê and Paraná meet, near the border of the Mato Grosso do Sul State.

The vegetation in the lake is dispersed in most low depth areas, near the lake's margin. The vegetation has a diameter that ranges between 5 and $7 \mathrm{~mm}$, a density of around 1000 plants $/ \mathrm{m}^{2}$ and a vegetation height of around 0.7 meters, located in shallow areas, 0.1 meters of which, are most usually above the water level.

\subsection{Data collection}

An extensive monitoring plan in this region is being carried out as well the definition of an alert system within the framework of the research project FINESP-ONDISA5. The objective is to develop predictive models for wind wave generation to be included in a warning system for navigation. Several wind and wave measuring campaigns have been undertaken.

The data acquisition system for wind velocity and its direction comprises 2D anemometers distributed around the lake and positioned $30 \mathrm{~m}$ high on lighthouses.

Once these field data are collected they are sent by radio telemetry to be processed and stored in the laboratory of Hydrology and Hydrometric of UNESP at Ilha Solteira. For the analysis and processing of wind data, the software OndisaCsat 3 
is used. This software automatically displays the results on a chosen interval, as follows: the number of samples taken, the wind average intensity, its frequency of occurrence, the wind direction and the highest winds. It has also the option of saving the original data to be able to analyze the raw data, to check it and compare results (Maciel et al., 2009, Morais et al. 2009).

Moreover, there is also a vertical structure $6 \mathrm{~m}$ tall implemented inside the lake, attached to a tree, where shell-type anemometers positioned at 0.3 , $0.6,1.2 \mathrm{~m}$ were attached, Figure 3 . The objective is to profile the wind data (used in the present work) at this site, which is made by the $2 \mathrm{D}$ anemometer, situated on top of this tower. The wind data have been recorded in a CR 1000 data-logger from Campbell Scientific. The shell-type anemometers are used to measure the wind speed only, while the 2D sonic anemometer measures wind speed and direction.

For wave measurements, a wave rider buoy and ADCP wave system, located at the bottom of the lake, are used. This last system is still under implementation and its data will be transmitted online to the central receiving data. An example of wave processing is shown on Figure 4.

In detail, the equipment deployed inside the lake and near the tree consist on (Figs. 3 and 4): (1) an ADCP-WAVES, which was deployed at $8 \mathrm{~m}$ depth, 20 meters away from the tree basis and connected via cable to the radio located in the instrumentation

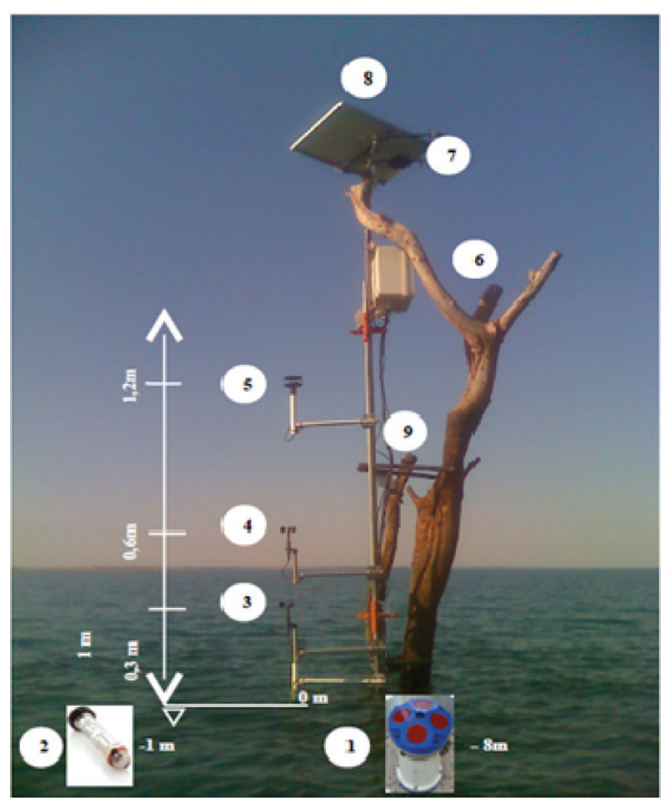

Figure 3. Instrumentation and telemetry.

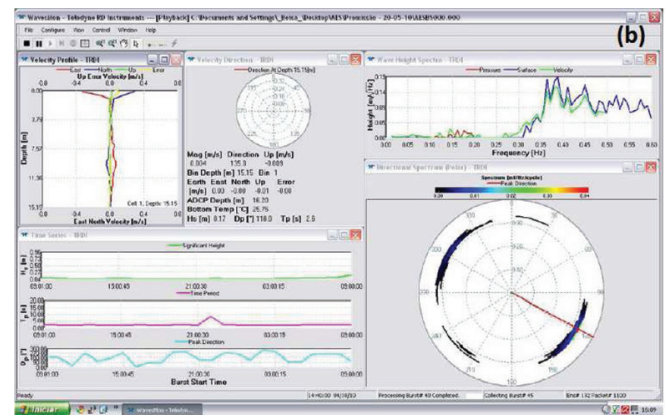

Figure 4. Wave processing software WAVESMON.

box; (2) a pressure transducer (Druck), which was deployed at $1 \mathrm{~m}$ depth and connected to the datalogger set/radio located in the box instrumentation; (3 and 4). Conventional shell-type anemometers, which are located at $0.3,0.6,1.2 \mathrm{~m}$ high on the structure tied to the tree; (5) a 2D Ultrasonic Anemometer, which was located at the top of the structure; (6) Box instrumentation, which contains radio, data loggers, batteries, etc; (7) Antennas for data transmission; (8) a solar panel power system, $80 \mathrm{~W}$; (9) a camera camcorder with high resolution and low power, for real time wave visualization.

\section{SWAN MODEL}

\subsection{Basic concepts}

The numerical model SWAN (Simulating WAves Nearshore) computes sea-wave generation, propagation and dissipation based on the wave action balance equation, Booij et al. (1999). This open-source wave model is being continuously upgraded by Delft University of Technology (The Netherlands).

The SWAN model is able to propagate sea waves from offshore up to the shoreline and takes into account the major physical processes of wave refraction, diffraction and shoaling due to bottom depth variation and to the presence of currents. It also includes wind induced wave growth, wave breaking due to bottom variation and to white-capping, energy dissipation by bottom friction, wave blocking and reflection as well as wave transmission.

The wave field at the study region is characterized by a $2 \mathrm{D}$ wave action spectrum which enables the model to represent the wave growth caused by wind or the presence of swell.

The required data to run the SWAN model are the bathymetry of the study region and the boundary conditions at the domain entrance, in addition to a set of computation parameters. Among the several results produced by SWAN it is worth 
mentioning the significant wave height, the average and the peak periods, directional spreading, the bandwidth parameter and the mean water level at any point of the defined computational domain.

\subsection{SWAN VEG}

In this paper, the SWAN-VEG (Suzuki et al., 2011) model is used. It is the original SWAN with the addition of the vegetation module, which contains an energy dissipation term due to vegetation that is subtracted from the incoming wave energy. This results in a lower wave height due to lower wave energy in and behind the vegetation area(s).

So, for waves propagating in a certain $\mathrm{x}$-direction, the wave energy flux, $\mathrm{F}$, remains constant if no energy, $\mathrm{E}$, is lost or gained, being $\mathrm{c}_{\mathrm{g}}$ the group velocity. This is denoted as:

$\frac{\partial \mathrm{F}}{\partial \mathrm{x}}=0 \rightarrow \frac{\partial}{\partial \mathrm{x}}\left[\mathrm{E} \cdot \mathrm{c}_{\mathrm{g}}\right]=0$

However, the vegetation causes a loss of energy resulting into a decrease of the wave energy flux and new wave conditions. Here the vegetation module determines an energy dissipation term $\varepsilon_{\mathrm{v}}$ $\left[\mathrm{kg} \cdot \mathrm{s}^{-3}\right]$ which is subtracted from the wave energy flux. The original SWAN model itself does not change, only an extra dissipation term is added to the model, equation 2 :

$\frac{\partial \mathrm{F}}{\partial \mathrm{x}}=-\varepsilon_{\mathrm{v}} \rightarrow \frac{\partial}{\partial \mathrm{x}}\left[\mathrm{E} \cdot \mathrm{c}_{\mathrm{g}}\right]=-\varepsilon_{\mathrm{v}}$

The vegetation is modelled as cylindrical obstacles causing drag force. This force is translated into an amount of energy that gives the following energy dissipation term $\varepsilon_{\mathrm{v}}$ based on Dalrymple et al. (1984) and Kobayashi et al. (1993) and according to Mendez \& Losada (2004).

The dissipation term is always negative as it causes a loss of energy. Equation 3 shows the dissipation term is a function of the following wave and vegetation conditions.

$$
\begin{aligned}
\varepsilon_{\mathrm{v}}= & \frac{1}{2 \sqrt{\pi}} \rho \mathrm{C}_{\mathrm{D}} \mathrm{b}_{\mathrm{v}} \mathrm{N}\left(\frac{\mathrm{kg}}{2 \sigma}\right)^{3} \frac{\sinh ^{3}(\mathrm{k} \alpha \mathrm{h})+3 \sinh (\mathrm{k} \alpha \mathrm{h})}{3 \mathrm{k} \cosh ^{3}(\mathrm{kh})} \\
& \times \mathrm{H}_{\mathrm{rms}}^{3}
\end{aligned}
$$

Vegetation is defined by four characteristics (height $-\alpha \mathrm{h}[\mathrm{m}]$; diameter $-\mathrm{b}_{\mathrm{v}}[\mathrm{m}]$; density of plants $-\mathrm{N}$ [plant $/ \mathrm{m}^{2}$ ] and drag coefficient $\left.-\mathrm{C}_{\mathrm{D}}[-]\right)$ and is modelled as cylinders which causes a drag force. Notice that $\mathrm{k}$ is the wave number, $\rho$ is the water density, $\sigma$ is the wave frequency, $g$ is the gravity,
$\mathrm{H}_{\mathrm{rms}}$ is the root mean square wave height. There is also a parameter used to quantify the vegetation, called vegetation factor $\left(\mathrm{V}_{\mathrm{f}}[\right.$ plant $\left./ \mathrm{m}]\right)$ given by:

$\mathrm{V}_{\mathrm{f}}=\mathrm{b}_{\mathrm{v}} \times \mathrm{N} \times \mathrm{C}_{\mathrm{D}}$

\section{APPLICATION OF SWAN MODEL}

The application of SWAN model to the study area of Ilha Solteira dam reservoir in order to characterize the waves in the presence of vegetation is herein described. Notice that the previous work of Vieira et al. (2013) which made an application of SWAN model, without vegetation, to this domain and compared numerical results with local wave measurements, showed a good perfomance of the model.

First, due to lack of detailed information on the vegetation, several sensitivity tests were performed on a constant depth bathymetry, varying the wind velocity and direction values as well as the characteristics of the vegetation (height, density, etc.). In this way we evaluate the effect of vegetation and its characteristics in this region. Then, for the real bathymetry, tests with and without vegetation are considered.

In the following sections, we present the input conditions of the model for the constant and real bathymetry. Numerical results are presented and discussed.

\subsection{Input conditions}

The domain calculation of the SWAN model was discretized with 3 grids, Figure 5 for constant

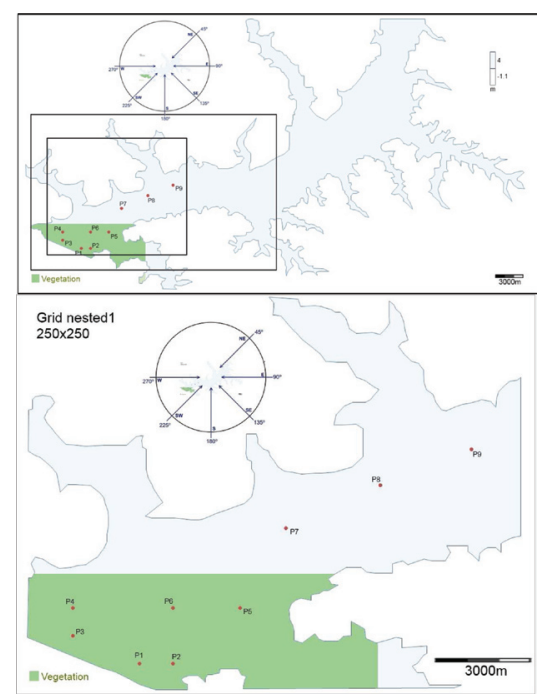

Figure 5. Constant Bathymetry: Grids with vegetation location. Vertical and horizontal scales in UTM. 
bathymetry, Figure 9 for real bathymetry. The largest grid is $58 \mathrm{~km}$ by $33 \mathrm{~km}$, the node spacing is $1000 \mathrm{~m}$ for constant bathymetry and $500 \mathrm{~m}$ for real bathymetry tests, and covers the whole Ilha Solteira dam reservoir. The following grid is, for constant bathymetry, $26.6 \mathrm{~km}$ by $28.4 \mathrm{~km}$ and with a $500 \mathrm{~m}$ distance between nodes. For the real bathymetry the second grid was considered to have $16.5 \mathrm{~km}$ by $13.5 \mathrm{~km}$ and $250 \mathrm{~m}$ of distance between nodes. For constant bathymetry, the third grid was considered to have $14.8 \mathrm{~km}$ by $14.3 \mathrm{~km}$ and $250 \mathrm{~m}$ between nodes, and for the real bathymetry tests, $11.3 \mathrm{~km}$ by $5.2 \mathrm{~km}$ and $503 \mathrm{~m}$ between nodes. Progressively more refined bathymetry files are used for each finer mesh, Figure 5. Several points (P1 to $\mathrm{P} 9$, although only P1, P6 and P9 for constant bathymetry and P7 and P9 for the real bathymetry, were used in this paper) were defined in order to obtain the SWAN results.
The directional spectrum in SWAN computations was defined with a frequency discretization of 30 intervals of 0.05 to $3.0 \mathrm{~Hz}$ with a logarithmic distribution and a directional discretization of $2.5^{\circ}$ covering the whole $360^{\circ}$ range (which gives 144 direction intervals). All the SWAN version 41.01, SWAN team (2014) runs were carried out in stationary mode, without the presence of currents. The physical phenomena included were at the three grids: refraction, diffraction, shoaling and wave breaking due to bottom influence and whitecapping. All the relevant parameters were introduced in the SOPRO-SWAN (Fortes et al. 2006) package.

\subsection{Constant bathymetry}

To test out the model, several cases were studied for a constant bathymetry (using the real frontier)

Table 1. Case conditions for constant bathymetry.

\begin{tabular}{|c|c|c|c|c|c|c|c|c|}
\hline Case & $\begin{array}{l}\text { Wind speed } \\
{[\mathrm{m} / \mathrm{s}]}\end{array}$ & $\begin{array}{l}\alpha h[\mathrm{~m}] \\
\text { (height) }\end{array}$ & $\begin{array}{l}\mathrm{b}_{\mathrm{v}}[\mathrm{m}] \\
\text { (stem } \\
\text { width) }\end{array}$ & $\begin{array}{l}\mathrm{N} \\
{\left[\text { plants } / \mathrm{m}^{2}\right]} \\
\text { (density) }\end{array}$ & $\begin{array}{l}\mathrm{C}_{\mathrm{D}}[-] \\
\text { (drag } \\
\text { coefficient) }\end{array}$ & $\begin{array}{l}\mathrm{V} \text { [plants } / \mathrm{m} \text { ] } \\
\text { (vegetation } \\
\text { parameter) }\end{array}$ & $\begin{array}{l}\text { Vegetation } \\
\text { details }\end{array}$ & Side notes \\
\hline 1 & 7.055 & - & - & - & - & - & None & - \\
\hline 2 & 7.055 & 4.3 & 0.015 & 60 & 0.8 & 0.72 & $\begin{array}{l}\text { Submerged } \\
\quad(0.7 \mathrm{~m} \text { below })\end{array}$ & - \\
\hline 3 & 7.055 & 4.3 & 0.015 & 258 & 0.8 & 3.096 & $\begin{array}{l}\text { Submerged } \\
\quad(0.7 \mathrm{~m} \text { below })\end{array}$ & - \\
\hline 4 & 7.055 & 4.3 & 0.2 & 60 & 0.8 & 9.6 & $\begin{array}{l}\text { Submerged } \\
\quad(0.7 \mathrm{~m} \text { below })\end{array}$ & - \\
\hline 5 & 7.055 & 4.3 & 0.07 & 258 & 1 & 18.06 & $\begin{array}{l}\text { Submerged } \\
\quad(0.7 \mathrm{~m} \text { below })\end{array}$ & - \\
\hline 6 & 7.055 & 5.5 & 0.015 & 60 & 0.8 & 0.72 & $\begin{array}{l}\text { Emerged } \\
\qquad(0.5 \mathrm{~m} \text { above })\end{array}$ & - \\
\hline 7 & 7.055 & 5.5 & 0.015 & 258 & 0.8 & 3.096 & $\begin{array}{l}\text { Emerged } \\
\qquad(0.5 \mathrm{~m} \text { above })\end{array}$ & - \\
\hline 8 & 7.055 & 5.5 & 0.2 & 60 & 0.8 & 9.6 & $\begin{array}{l}\text { Emerged } \\
\qquad(0.5 \mathrm{~m} \text { above })\end{array}$ & - \\
\hline 9 & 7.055 & 5.5 & 0.07 & 258 & 1 & 18.06 & $\begin{array}{l}\text { Emerged } \\
\qquad(0.5 \mathrm{~m} \text { above })\end{array}$ & - \\
\hline 10 & 14.11 & - & - & - & - & - & None & $\begin{array}{l}\text { Case } 1 \text {, } \\
\quad \text { double speed }\end{array}$ \\
\hline 11 & 14.11 & 5.5 & 0.07 & 258 & 1 & 18.06 & $\begin{array}{l}\text { Emerged } \\
\qquad(0.5 \mathrm{~m} \text { above })\end{array}$ & $\begin{array}{l}\text { Case } 9, \\
\quad \text { double speed }\end{array}$ \\
\hline 12 & 14.11 & 5.5 & 0.01 & 10 & 1 & 0.1 & $\begin{array}{l}\text { Emerged } \\
\qquad(0.5 \mathrm{~m} \text { above })\end{array}$ & $90 \%$ wgpr \\
\hline 13 & 7.055 & 5.5 & 0.01 & 10 & 1 & 0.1 & $\begin{array}{l}\text { Emerged } \\
\quad(0.5 \mathrm{~m} \text { above })\end{array}$ & $90 \%$ wgpr \\
\hline 14 & 7.055 & 5.5 & 0.01 & 10 & 1 & 0.1 & $\begin{array}{l}\text { Emerged } \\
(0.5 \mathrm{~m} \text { above }) \\
\text { nwiv }\end{array}$ & $\begin{array}{r}90 \% \text { wgpr; } \\
45^{\circ} \text { only }\end{array}$ \\
\hline 15 & 14.11 & 5.5 & 0.01 & 10 & 1 & 0.1 & $\begin{array}{l}\text { Emerged } \\
(0.5 \mathrm{~m} \text { above }) \\
\text { nwiv }\end{array}$ & $\begin{array}{r}90 \% \text { wgpr; } \\
45^{\circ} \text { only }\end{array}$ \\
\hline
\end{tabular}

${ }^{*}$ wgpr — wet grid points requirement; ${ }^{*}$ nwiv—no wind inside vegetation. 
using 4 meters of water depth inside the whole lake and 1 meter plus due to rainfall. 9 points were analyzed and vegetation applied on a specific "corner" of the grid, as shown in Figure 5.

Eleven case studies were calculated, changing several parameters and conditions, as shown in Table 1 . Wind directions of $45^{\circ}, 90^{\circ}, 135^{\circ}, 180^{\circ}$, $225^{\circ}$ and $270^{\circ}$ were considered. Two values for the velocity magnitude $(7.055$ and $14.11 \mathrm{~m} / \mathrm{s})$ were also tested. The characteristics of vegetation were also varied: two heights ( $\alpha$ h), 4.3 and 5.5 meters; four stem width $\left(\mathrm{b}_{\mathrm{v}}\right)$ values, $0.015,0.2,0.7$ and 0.01 meters; three values of density $(\mathrm{N}), 60,258$ and 10 plants $/ \mathrm{m}^{2}$ and two drag coefficients $\left(\mathrm{C}_{\mathrm{D}}\right)$ 0.8 and 1 . These lead to five different vegetation parameter $\left(\mathrm{V}_{\mathrm{f}}\right)$ values: $0.72,3.096,9.60,18.06,0.10$ plants $/ \mathrm{m}$.

Graphs showing wave height (Hs) were plotted by the wind directions for points P1, P6 and P9, Figures 6, Figure 7 and Figure 8, respectively. These points were chosen due to the fact that they are lined up in the longest extension of the lake and are included in all of the three grids. The plots were traced with data from grid 3 $(250 \times 250$ meters $)$. The cases were split up to be more feasible to compare vegetation characteristics. All tests are compared with the ones without vegetation.
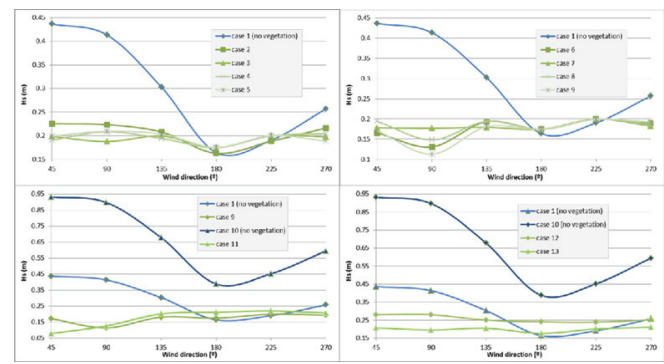

Figure 6. Constant bathymetry-Case comparison for point $\mathrm{P} 1$.
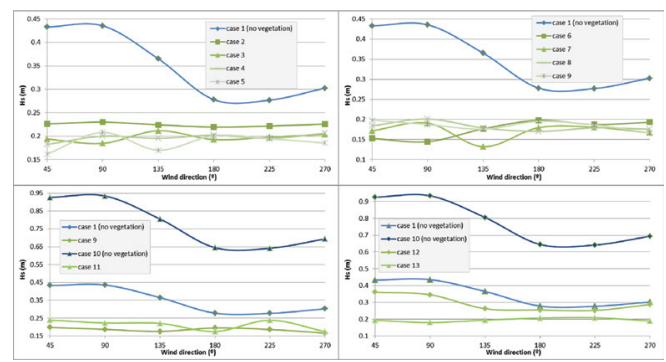

Figure 7. Constant bathymetry-Case comparison for point P6.

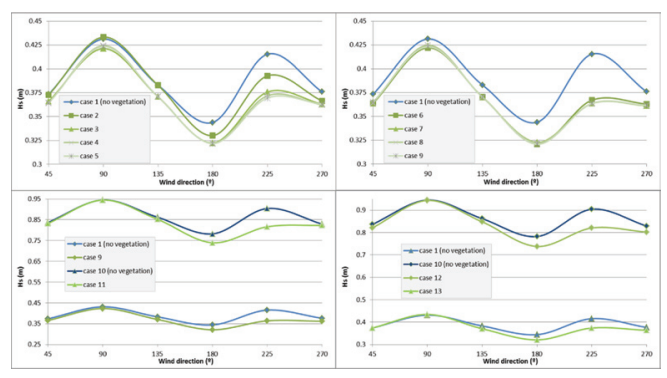

Figure 8. Constant bathymetry. Case comparison for point P9.
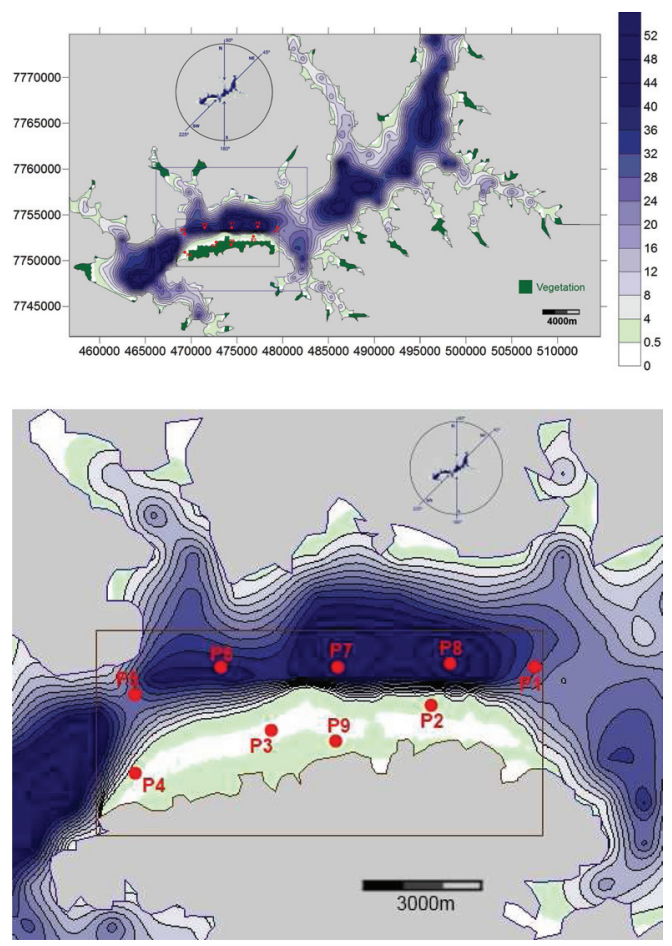

Figure 9. Real bathymetry with vegetation and grids. Points P1 to P9. Vertical and horizontal scales in UTM.

From the figures above, it is reasonable that for the points P1 and P6 inside the vegetation area, the wave heights with vegetation are lower than ones without vegetation. This difference is even more noticeable in the cases where the wind velocity is higher. In the cases where the vegetation is emerged, the wave heights are higher than when it is submerged, as expected. The variation of the wave heights with the wave direction is insignificant for P1 and P6 for the vegetation cases, as it happens for the cases without vegetation. In fact, in 
those cases without vegetation, Hs is higher for the wave directions between $45^{\circ}$ and $135^{\circ}$ and is significantly lower for the other directions due to a much lower fetch. We also noticed that the variation of Hs is not significant with the vegetation parameter (Vf) although it is noticeable a minimum reduction when it is higher than 3 plants $/ \mathrm{m}$. The Hs values of point $\mathrm{P} 6$ are higher than $\mathrm{P} 1$ since it is closer to the border vegetation area.

For P9, Figure 8, the Hs values are not significantly affected by the presence of vegetation, except for the directions $180^{\circ}$ to $270^{\circ}$, due to lower fetch.

\subsection{Real bathymetry}

The domain and vegetation areas for the real bathymetry are shown on Figure 9. All areas with depths equal or higher than 0.7 meters were considered to have vegetation. Several points (P1 to P9) were defined in order to obtain the SWAN results, although only $\mathrm{P} 7$ and $\mathrm{P} 9$ will be further discussed in this paper. Calculations were made using SWAN grids different from the constant tests and the seven studied cases were as presented in Table 2. Due to the lack of information on vegetation characteristics of the area, the same tests as in the constant bathymetry were made in order to analyse the influence of the bathymetry. Visiting one of the margins of the lake allowed to analyse the characteristics of the vegetation. A supplementary test (case 7) was made, as an attempt to reproduce those characteristics.

Wind directions of $45^{\circ}, 90^{\circ}, 180^{\circ}$ and $225^{\circ}$ were considered. Four values for the velocity magnitude $(3.53,7.055,10.58$ and $14.11 \mathrm{~m} / \mathrm{s}$, based upon local wind measurements) were also tested. The only vegetation height $(\alpha \mathrm{h})$ studied was $0.7 \mathrm{~m}$, as it was directly observed. The other characteristics of vegetation were also varied: five stem width $\left(b_{v}\right)$ values, $0.015,0.2,0.7,0.01$ and 0.006 meters; four values of density $(\mathrm{N}), 10,60,258$ and 1000 plants/ $\mathrm{m}^{2}$ and three drag coefficients $\left(\mathrm{C}_{\mathrm{D}}\right)$ 0.8, 1 and 0.6 . These lead to six different vegetation parameter (V) values: $0.10,0.72,3.096,9.60,18.06$ and 3.6 plants/m.

Figure 10 and Figure 11 present the significant wave heights for points P7 and P9, for the four studied wind speeds, for the cases 1 to 7 .

The results presented for the real bathymetry showed that there is a significant reduction of $\mathrm{Hs}$ in test cases with vegetation and in the points (P9) inside the vegetation area. The variation of wave direction does not affect significantly the reduction

Table 2. Cases conditions for real bathymetry.

\begin{tabular}{llllll}
\hline Case & $\begin{array}{l}\alpha \mathrm{h}[\mathrm{m}] \\
\text { (height) }\end{array}$ & $\begin{array}{l}\mathrm{b}_{\mathrm{v}}[\mathrm{m}] \\
\text { (stem width) }\end{array}$ & $\begin{array}{l}\mathrm{N}\left[\mathrm{plants} / \mathrm{m}^{2}\right] \\
(\text { density) }\end{array}$ & $\begin{array}{l}\mathrm{C}_{\mathrm{D}}[-] \\
\text { (drag coefficient) }\end{array}$ & $\begin{array}{l}\mathrm{V} \text { [plants } / \mathrm{m}] \\
\text { (vegetation parameter) }\end{array}$ \\
\hline 1 & - & - & & - & - \\
2 & 0.7 & 0.01 & 10 & 1 & 0.1 \\
3 & 0.7 & 0.015 & 60 & 0.8 & 0.72 \\
4 & 0.7 & 0.015 & 258 & 0.8 & 3.096 \\
5 & 0.7 & 0.2 & 60 & 0.8 & 9.6 \\
6 & 0.7 & 0.07 & 258 & 1 & 18.06 \\
7 & 0.7 & 0.006 & 1000 & 0.6 & 3.6 \\
\hline
\end{tabular}
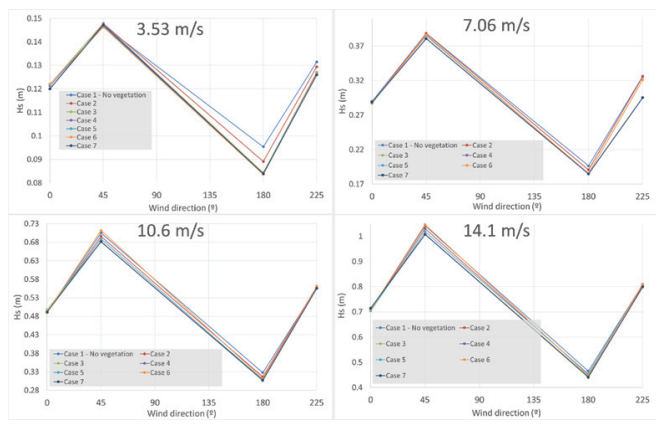

Figure 10. Real bathymetry-Case comparison for all wind speed in point P7.
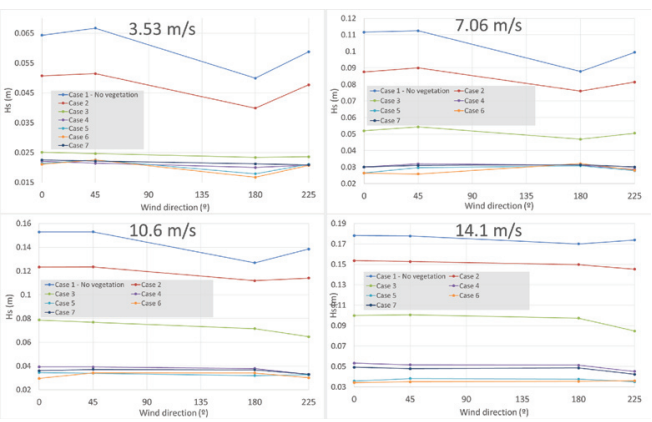

Figure 11. Real bathymetry-Case comparison for all wind speed in point $\mathrm{P} 9$. 
of Hs. As the wind velocity increases, the Hs in the points outside the vegetation area also increases and the reduction in $\mathrm{Hs}$ is smaller in points located inside the vegetation area.

\section{CONCLUSIONS}

This paper presented the application of SWANVEG model, SWAN Team (2014), to the study region of the dam reservoir of Ilha Solteira, São Paulo, Brazil. The model was used to simulate the wind-generated waves at the reservoir, considering the situation with and without vegetation.

Some sensitivity tests were first performed on a constant depth bathymetry, varying the wind and the vegetation conditions. It was shown that there is a significant reduction when a vegetation area is considered and for the points inside or nearby that area. This is more evident in the cases where the wind velocity is higher. Moreover there is no significant variation of $\mathrm{Hs}$ with the wave direction.

In the real bathymetry, the conclusions were the same although the reduction on the wave heights is less evident than the verified in the constant case.

The characterization of the vegetation in the Ilha Solteira lake and comparisons with field measurements will constitute future work.

\section{ACKNOWLEDGEMENTS}

This study is funded by the FCT under the contracts of HIDRALERTA project-Flood forecast and alert system in coastal and port areas, ref. PTDC/AAC-AMB/120702/2010, EROS project and FCT/CAPES (Brazil) project-"Building a Base for Research and Knowledge in Coastal Engineering". The authors acknowledge the support made possible by the projects financed by CAPES - Conselho Nacional de Desenvolvimento Cientifico e Tecnológico contracts of refs. 0022101 and PPGEE/FEIS-UNESP_Programa de Pós Graduação em Engenharia Elétrica-Faculdade de Engenharia de Ilha Solteira-Brazil.

\section{REFERENCES}

Booij, N., Ris, R.C. \& Holthuijsen, L.H. 1999. A Thirdgeneration Wave Model for Coastal Regions, Part I, Model Description and Validation. Journal Geophysical Research, 104 (C4), pp. 7649-7666.
Dalrymple, R.A., Kirby, J.T. \& Hwang, P.A. 1984. Wave diffraction due to areas of energy dissipation. $J$. Waterw. Port Coast. Ocean Eng. 110, 67-79.

Fortes, C.J.E.M., Pinheiro, L.V., Santos, J.A., Neves, M.G. \& Capitão, R. 2006. SOPRO —Pacote integrado de modelos de avaliação dos efeitos das ondas em portos. Tecnologias da Água, Edição I, March, pp. 51-61.

Kobayashi, N., Raichle, A.W. \& Asano, T. 1993. Wave attenuation by vegetation. J. Waterw. Port Coast. Ocean Eng. 119, 30-48.

Maciel, G.F; et al. 2009. Alerta de ventos e ondas para a segurança da navegação. Proc. $6^{\circ}$ Seminário de Transporte e Desenvolvimento Hidroviário Interior. Rio de Janeiro, 21 and 22 October.

Mendez, F.M. \& Losada, I.J. 2004. An empirical model to estimate the propagation of random breaking and nonbreaking waves over vegetation fields. Coastal Engineering 51, 103-118.

Morais, V.S., Cunha, E.F. \& Maciel, G.F. 2009. "Medição, Previsão e Análise Numérica dos Mecanismos de Geração de Ondas a Partir da Cinética de Ventos e Dissipação de Ondas na Presença de Fundos com Vegetação, em Lagos de Barragens", Proc. XVIII Simpósio Brasileiro de Recursos Hídricos. Campo Grande-Mato Grosso do Sul_Brasil: Anais do XVIII Simpósio Brasileiro de Recursos Hídricos.

Suzuki, T., Zijlema, M., Burger, B., Meijer, M.C. \& Narayan, S. 2011. Wave dissipation by vegetation with layer schematization in SWAN. Coastal Engineering $59,64-71$.

SWAN Team 2014. SWAN scientific and technical documentation. SWAN Cycle III version 41.01. Report. Delft University of Technology.

UNESP 1997, 2008. ONDISA Project. Project support by FAPESP and FINESP Brazilian agencies.

Vieira, A., Fortes, C.J.E.M., Maciel G.F. \& Minussi C.R. 2011. "Comparative analysis of wind generated waves on the Ilha Solteira lake, by using numerical models OndisaCAD and SWAN". Proc. 5th SCACR International Short Conference on applied coastal research, Aachen, June.

Vieira, A.S., Maciel G.F., Fortes, C.J.E.M., Minussi, C.R. \& Sobrinho, M. Dall'Aglio 2013. "Comparative analysis of the SWAN numerical model predictions and of the pressure sensor measurements at the Ilha solteira Lake". Proc. 6th SCACR-International Short Course/Conference on Applied Coastal Research, 4-7 June, LNEC, Lisbon. 